\title{
Salvation in Non-Christian Religions: Approaches of Christian Theologians in the Post Modern Era
}

\author{
Muhammad Shahid Habib \\ Ph.D Scholar and Visiting Lecturer, Department of Comparative Religion, International Islamic University, Islamabad, Pakistan \\ Email: shahid.habib@iiu.edu.pk
}

\section{Doi:10.5901/mjss.2015.v6n3s2p163}

\section{Abstract}

The Church believes in the salvation of the followers of the other faiths as it is the Divine Will. This development of thought about other faiths was the result of many prominent Christian theologians. Among them was Karl Rahner who coined the term "anonymous Christians" for the non-Christians. Rahner ensures that the Christian message lawfully led the non-Christians to eternal salvation. To another influential theologian John Hick, God is the focal point of salvation. His universal love is the key to salvation for all humans. Hans Kung was an advocate of inclusivism. He affirms that there is salvation outside the church but only through Christ who does not confine his salvific grace to Christians only. Paul Knitter a Roman Catholic theologian insists that Christians must regard other responses as salvific because of universal will of God. Christ, to him is the final cause of salvation. The most creative theologian among the contemporary Americans was John Cobb who assigns special meaning to the term "Christ". To him, Christ is the way that excludes no ways. To Edward Schillebeeckx, salvation is encountered in the daily living and worshiping of humans. The documents of the second Vatican Council also promote fellowship with different religions as all are heading toward the one God and all the prophets carried the His plan of salvation. The objectives of the study are to explore the approaches of Christian theologians in the post-modern era. The study is descriptive in nature. Internal and external criticism has been done to meet the objectives of the study. The study is significant for the religious scholars, researchers and curriculum developers.

Keywords: Exclusivism, Inclusivism, Pluralism, Salvation, Theology, Christian, Religion, Karl Barth, Karl Rahner, John Hick, Hans Kung, Paul Knitter F., Johnn Cobb, Edward Schillebeeckx and Vatican II

\section{Introduction}

Christianity, in development of its thought present today carries the different phases which form the two thousand years of its history. The view about other faiths was formed in a period of substantial ignorance of the wider religious life of mankind. In first place, there was found total rejection for the other religions as there was no salvation outside the Church. (A. Race, 1983) This is called exclusivism. The second stage led the Catholic thinkers to better understanding of other faiths rejecting the rejection phase. This phase is termed as inclusivism.

The modern and the post-modern era saw the globalization of the world and the societies became multi-cultural and multi-religious resulting in the fruitful struggle for the promotion of tolerance, harmony and understanding among people of different religions and faiths. This led the theologians to rethink the religious matters for peaceful social setup resulting in the phase of Pluralism. Of the three, exclusivism was propounded and propagated by Karl Barth. It was Karl Rahner who chiefly advocated the concept of inclusivism. Pluralism was led and supported by John Hick. The development of these concepts show the Christians' tendency towards the acceptance of non-Christian religions entitled to salvation as the universal will of God. The following paragraphs will illustrate the three phases in detail.

\section{The Three Fold Typology and Ways of Salvations}

\subsection{Exclusivism in Christian Tradition}

The exclusivists hold that there is only one true, saving religion i.e., Christianity. The Christian doctrine "extra ecclesiam mulla salus" has played a vital role which meant that there is no salvation outside the Church. Luther said, "Those who are outside Christianity, be they heathens, Turks, Jews, or even false Christians and hypocrites cannot expect, either love or any blessing from God, and accordingly remain in eternal wrath and perdition". (J. Hick, 1985) The Christians hated the non-Christians. Their mission carried the responsibility of conversion of non-Christians to Christianity. About this, Julius 
Richter states that it is a subject of missiology which is:

"That branch of theology which in opposition to the non-Christian religions shows the Christian religion to be the way, the truth, and the life which seeks to dispossess the non-Christian religions and to plant in their stead in the soil of heathen national life the evangelic faith and the Christian life". (J. Hick and F. Knitter, 1987)

It was considered extremely necessary for salvation. The Christian understanding of God is as holy love and of Christ as the divine love incarnate. On this basis, there remained the attitude of total rejection for a long time. The Christians had been too strict towards other religions. The main reason behind that had been the total ignorance of them. There was kept a distance from the other religions which continued to add to the hatred for them. This was an age of Exclusivism when the Christians thought none entitled to salvation outside the Church.

\subsection{Inclusivism \& Christian Theologians}

The intellectuals went deep into the Protestantism followed by the positive interaction to the non-Christian faiths. It was considered that only Catholics could be saved. Anyone except them to be saved would have been Catholic without knowing it. All the Muslims, Jews, Hinduism etc believe themselves what they are but they in fact are the members of mystical body of Christ. The Christian theology views the divine presence in them. However, they are considered as having no salvation apart from Christ. The inclusivist approach is that all the religious truths belong to the Christ. Inclusivism includes other religions as having divine presence but salvation becomes possible only through Christ in an implicit way. The Christians claim of the Christianity's unique finality as the laws of the only full divinity and full salvation. The non-Christians can be saved only because of their union to Christ in a way unknown to them. (J. Hick and F. Knitter, 1987)

Since the Second Vatican Council, the inclusivist theology of religions is described as "Christ within the religions". The theologians propounding this view were Karl Rahner; Hans Kung, Rawan Williams, David Tracy etc. They stated that the grace of Christ is an essential element for salvation, however implicit in all other faiths. It is only Christianity which explicitly carries full salvation. The whole theme had effectively been explained by Pope Pius IX in 1854:

"It must, of course, be held as a matter of faith that outside the apostolic Roman Church, no one can be saved, that the Church is the only ark of salvation, and that whoever does not enter it will perish in the flood. On the other hand, it must likewise be held as certain that those who are affected by ignorance of the true religion, if it is invincible ignorance are not subject to any guilt in this matter before the eyes of the Lord." (J. Hick, 1985)

This view clearly illustrates that eternal salvation is possible only within the Church. However, believers of other faiths can be saved if they belong to the Church at least in desire and longing as it is not always necessary that this desire be explicit.

\subsection{Religious Pluralism \& Christian Theologians}

Pluralism according to the Oxford Dictionary means "a condition in which two or more states, groups, principles co-exist". (M. Eliade, 1987) It was first debated by John Hick who stated that religious pluralism is the fact that the history of religions shows a plurality of traditions. Pluralism refers to a particular theory of the relation between these traditions. Regarding religions, pluralism is also used for theocentrism. In pluralistic approach in theology, ingenuity goes to the extent to hold together that outside Christianity there is no salvation and that outside the Church there is salvation. This acknowledges an evident fact that salvation in experiential form lies both inside and outside the Church. (J. Hick, 1985) Their being Christian is, however implicit and not explicit. For such kind of Christians, Karl Rahner has coined the term Anonymous Christian. Another Christian theologian, Hans Kung daringly expressed, "A man is to be saved within the religion that is made available to him in his historical situation". (J. Hick, 1985) All the world religions carry the way of universal salvation. The difference between the Salvation of the Church and outside is that in the former, it is very especial and extra-ordinary.

\section{Karl Rahner and the Theory of Anonymous Christian}

Karl Rahner (1904-1984) was a German Catholic theologian of the twentieth century. (W. Dych, 1992) He developed a sort of modern theology which deeply influenced not only the Catholic Church but also other Christian sects. (G. Michael, 
and Monika K., 2004) He is considered to be the pioneer of Inter-religious dialogue (K. Rahner, 1960-1991) and emerged as a leading figure of Vatican (1962-1968). (F. Cross, 1997) It's developing of Christian attitude towards other religions carries Karl Rahner as the chief engineer in this regard. (C. Padraic and Franche R., 2010) The documents and later results of Vatican II are unthinkable apart from his contributions. $(\mathrm{H}$. Vorgrimler, 1986) Rahner clarifies this in his article on "Christianity and non-Christian religions". (K. Rahner, 1998) It carries in it four theses. Firstly, Christianity claims to be the absolute religion intended by God for all but the human persons meet it when they are seriously confronted by it. (K. Rahner, 1966) At the second place, he discussed the social aspect of salvation. The humans are religious to attain salvation through a concrete religion in which they find themselves. Because of confrontation with the Christian message, non-Christian religions are lawful leading to salvation. (K. Rahner, 1966) The third thesis recognizes the followers of other faiths as anonymous Christians because of their implicit relation to Christ. (K. Rahner, 1966) Last thesis reflects upon the idea of mission. (K. Rahner, 1966) The term anonymous Christiansmeant to clarify and broaden the outlook of the Catholic Church on the followers of other faiths (K. Joseph, 1987)

\section{Huns Kung and Ways of Salvation}

Another loud voice regarding religious pluralism is Hans Kung who was born in Sursee, Switzerland in 1928. He is a prominent theologian, philosopher and a prolific writer. From 1960 till his retirement in 1996, he served as the Professor of Ecumenical Theology and Director of the Institute for Ecumenical Research at the University of Tübingen. From 1962 to 1965, he rendered his services as official theological consultant (Peritus) to the Second Vatican Council appointed by Pope John XXIII. (M. Anderson, 2014)

As a younger theologian, he has developed his argument in the context of the dogma "Outside the Church no salvation". Kung's first conception is that there is salvation outside the Church, But only through Christ. Christ does not confine his salvific grace to Christians only. Kung explains that the salvation the salvation of non-Christians is not on the basis of Church but it is because of faith in God. Church is to be understood as an open community of those who serve and help. There is God's nearness to all persons of goodwill and God's grace for eternal salvation of mankind. (H. Kung, 1976)

Kung considers all the religions having truth concerning the true God but they are in error. The gospel states to convert the non-Christians but does not require them to renounce "Whatever is true, whatever is honorable, whatever is just, whatever is pure, whatever is lovely, and whatever is gracious". (R. Drummond, 1985)

The proclamation of God's truth in some way leads the followers of these religions to salvation. Regarding this Kung further explains:

"As against the "extraordinary" way of salvation which is the Church, the world religions can be called-if this is rightly understood-the "ordinary" way of salvation for non-Christian humanity. God is the Lord not only of the special salvation history of the Church, but also of the universal salvation history of all mankind; this universal history is bound up with the especial salvation history in having a common origin, meaning and goal and being subject to the same grace of God." (R. Drummond, 1985)

For Kung, the ordinary salvation is general for all non-Christians whereas the Church guarantees extra-ordinary salvation for the Christians. He removes the question from the issue of their eternal salvation. Both kinds of salvation are bound together in the common meaning of God. Christian faith according to Kung carries this as its integral part that all the humans the humans are saved by the will of God; and that they are intended to find their salvation. To God, religions are serial strictures and potential vehicles for the operation of divine grace. Kung further affirms that they have a relative validity and a relative providential right to existence. They are theologically pre-Christians. (R. Drummond, 1985)

This theme has been shown in his both work on being a Christian. Kung always wrote with passion, rich learning and insight. He emphasizes the universal perspectives of the Bible that God is creator and converse of all men, that God operates everywhere that he wills the salvation of all men and that the non-Christians too as observers of law can be justified. Kung most absolutely emphasizes that there is salvation outside the visible Church. The other religions may be ways of salvation having authentic theological legitimacy.

\section{Paul F. Knitter and his Theory of Salvation}

Among Roman Catholic theologians, Paul F Knitter was the Professor of Theology, World Religions and Culture at Union Theological Seminary in the City of New York. (F. Knitter, 2014) He was formerly Emeritus Professor of Theology 
at Xavier University in Cincinnati, Ohio. Since publishing His acclaimed book, No Other Name? (1985), made him quite famous as he devotedly advocated the religious pluralism. The survey of religious pluralism carried three distinct approaches?

(i) All religions are relative.

(ii) All are essentially the same.

(iii) All have a common psychological origin.

To Knitter, the Catholic mode of pluralism has three major insights. At the first place, Christians must regard other religions as salvific because of universal will of God. Secondly, Christ is the final cause of salvation. Third insight is that interfaith dialogue to learn from other religions. This is seen as the "new age" for Christianity. Knitter continues to insist on the proclamation of Christ as "the norm above all other norms the "definite savoir". (F. Knitter, 1985)

To him, the current era of dialogue must supers both the New Testament witness and Christian tradition. Knitter summarizes his position in term of seeking a common experience among the various religions of the world in the following way:

"Instead of searching for 'one God' or 'one Ultimate' or a common essence' or a 'mystical centre' within all religions, we can recognize a shared locus of religious experience now available to all the religions of the world". (F. Knitter, 1985)

He takes pluralism to its logical conclusion which is in contrast to anonymous Christianity explained by Rahner. (F. Knitter, 1996)

In his book, "Introducing theologies of religions", Paul Knitter invites his readers to view religious pluralism as a promise and a providential blessing instead of considering it as a problem or threat. Knitter's vision carries global dialogical community. He has presented four main theological modes for Christian religion on other religions. First is the Replacement Model of the optimistic views as the reality of other religions is known to the Western world. (F. Knitter, 2002) The second one is the Fulfillment Model which is the most typical of the Vatican II Roman Catholic Theology. The third model is the Mutuality Model which is relatively a new approach. This model leads to a platform for more authentic dialogue. The last one is the Acceptance Model which welcomes religious plurality and makes no assumptions concerning other religions. There is no common ground among religions but there is a large space for dialogue in the sense of a good neighbor policy. (F. Knitter, 2002)

\section{John Hick and his Idea of Universalism}

An influential religious pluralist who contributed a lot to the understanding of the concept of salvation in the non-Christian religions (J. Hick, 1986) was John Hick (1922-2012). He proved to be one of the most important and great theologians of the twentieth century. As a philosopher in the Anglo-analytic tradition, his works mark the foundation of religious epistemology, philosophical theology, and religious pluralism. (J. Hick, 2002) To him, all the world religions worship God who has been given various names. He has advocated a paradigm shift replacing Christianity by God as focal point of salvation. (J. Hick, 1973) John Hick explains the pluralistic approach towards religion in the following words:

"It must involve a shift from the dogma that Christianity is at the centre to the thought that it is God who is at the centre and that all the religions of mankind, including our own, serve and revolve around him". (J. Hick, 1985)

This is the advocacy of "Copernican revolution" which involves a new Christianity. It is mythical in nature and needs re-interpretation and this is its uniqueness. Hick takes pluralism to its logical conclusion, a radical redefinition of the Christian faith where its fundamental doctrines are destroyed. (G. D'Costa, 1987) He demythologizes the Christian faith and removes Christ from the centre of divine revelation. To him, "Any viable Christian theodicy must affirm the ultimate salvation of all God's creatures". (G. D'Costa, 1987)

When Hick states that theodicy must affirm the ultimate salvation of all God's creatures, it guides to think whether there is no life and death decision is to be made. It can be assumed that everything will turn out well for everyone in the end. (G. D'Costa, 1997)

Thus Universalism is highly appealing for modern man though it is not biblical. Regarding salvation of mankind, Hick's view contrasts to that of the Christ who asked, "Lord, will those who are saved be few"? The reply to this question was strive to enter the narrow door; for many i tell you, will seek to enter and will not be able. (C. Chales M., 1997)

Hick's emphasis has been on the choice of love of God instead of his judgment. God's love carries universality and leads the whole world to salvation. This love calls for the response of faith in Jesus Christ. Hick's goes beyond and states the God's love must lead to the salvation of all creatures. Hick exhorts us to take the love of God for faith in Christ 
seriously. The scripture speaking of salvation means both the love of God in faith in Christ. Hick boldly declares that Christianity has numerable resources capable of being developed in the interests of a world ecumenism. A view of Hick's theology makes it clear he shows little respect for the Scripture and prefers the pluralist environment of contemporary society. He has criticized Rahner's notion of anonymous Christianity in the following words. "These rather critical theories are all attempts to square an inadequate theology with the facts of God's words". (J. Hick, 1985)

\section{John B. Cobb and Salvation}

Among the most creative and influential contemporary American theologians, John Cobb (1925) stands high whose work "Christ in a Pluralist Age" appeared to be the most significant Christological study. Cobb finds the universal presence of revelation and redemptive grace. Every actuality is offered an initial aim by God who is a transcendent source. (R. Drummond, 1985) Successful appropriation of the new aim will read to creative transformation in the world. Cobb designates it as Logos having Christ as its incarnation in the world, especially the human beings. This makes Jesus "the paradigm case of incarnation. (R. Drummond, 1985) His existence is characterized by his identity with the immanent Logos. Jesus alongside it is also the highest embodiment of human being. Cobb explains the saving significance of the paschal mystery of Jesus in terms of a spiritual field of force into which people can enter". This makes Cobb's Logos Christology constitutive as well as normative. To him, it has become outdated for Christians to view the other faiths in a negative way. Cobb assigns special meaning to the term "Christ". (R. Drummond, 1985) He identifies Christ as the image of creative transformation. To him, Christ is the way that excludes no ways. He can provide unity in religious history of mankind. The existence with openness to the other great religions of mankind can lead to a deepening of Christian existence. Cobb has used the term 'Logos' to denote the cosmic principle of order, the ground of meaning and the source of purpose. Logos equates to the mind of God. Christ is the Logos as incarnate and Jesus is the full incarnation goes Logos. Cobb clears that the nature of the ultimate divine reality is to be regulated by the nature of the personhood of Jesus. (R. Drummond, 1985)

\section{Edward Schillebeeckx and Culture of Theology}

Edward Schillebeeckx had been extremely influential on Roman Catholicism emerging prior to Vatican II and continuing beyond its promulgations. In the modern context of theology, Schillebeeckx elaborated "a theological perspective on the historical form of human existence in its concrete involves mint with the world and its religious meaning". (E. Borgman, 2003) He envisaged a new partnership between Church and the World. To him, Church has to link itself with the questions implicit in the contemporary sensibilities. Salvation is encountered in the daily living and working of human beings in the world in their relation with what is on the earth. He emphasizes on actually putting the teachings in the documents into practice by Christians. In non-Christian religions, Schillebeeckx views the basic evangelical of the one true Church of Christ. In this regard, it is stated, "Everyone, including even a well-disposed agnostic, has some connection with This Church and is not a complete outsider". (E. Schillebeekx, 1967)

Schillebeeckx regards it as "a first step in a sincere but prudent dialogue". It was both to receive from and to give to the world and its religions. He further notes that the Council affirms the non-Christian religions as part of God's redemptive plan. (E. Schillebeekx, 1967)

Schillebeeckx's theology is premised on the need for hermeneutics. Theology is about discerning God's dialogue with the world which is always in interpretted from as it is always within a particular context. Schillebeeckx believes that it is faithfulness to Gospel to re-interpret it i.e. "to present the original Dialogue (a living prophecy!) again and again, and above all to put it into action and to let it be heard as the word of God in constantly changing situations in life." (E. Schillebeekx, 1967) Such is the task of hermeneutics theology and the Church.

\section{Second Vatican Council Documents and Salvation for non-Christians}

Towards the last part of the $20^{\text {th }}$ century, there appeared "The "Declaration on the Relationship of the Church to NonChristian Religions". With this document in 1965 the Church affirmed all the mankind with different religion as one community. (F. Edmund, 2001) The Church examined the relation with other faiths with greater care. It looked for the common values to promote fellowship among them as all share the common destiny i.e., God. His saving will extends to all mankind. Men look to their religions for an answer to the undiscovered issues like what is man and what is the life for? What happens after death or what is judgment etc. All the religions carry a certain awareness of a hidden power along with the recognition of the Supreme Being. (Vatican Council, 1965) 
In this context, the stance of the Church is appreciable. It does not reject anything which is true and holy in other religions. This is because many of its teachings reflect the truth that enlightens all mankind way. Christ however is proclaimed as "The way, the truth and the life". He carries in him the fullness of religious life for all men. It is mindful that the Church stands on the descended pillars and apostles. The Church always held that Christ underwent suffering and death became of the sins of all men so that all might attain salvation. The cross of Christ is proclaimed as sign of God's universal love and grace for all.

\section{Conclusion}

The salvation of the followers of the other faiths is the Divine Will. This development in Church's consideration passed through three stages namely exclusivism, inclusivism and pluralism which developed respect for every religion. This development of thought about other faiths was the result of many prominent Christian theologians and the church restated its theology in a reformed manner. Among them was Karl Rahner who coined the term "anonymous Christians" for the non-Christians. Rahner ensures that the Christians message lawfully leads all to eternal salvation. To him, transcendentalism is the most distinctive characteristic of human beings keeping them in relation with God. Another influential theologian was John Hick replaced Christianity by God as the focal point of salvation. To him, all the world religions are the human responses to the one reality i.e., God. He declares that Christianity can develop in the interest of world ecumenism. Hans Kung was an advocate of inclusivism. Kung considers all the religions having truth but they are in error. For Kung, all the non- Christians will have salvation. Pluralism was also surveyed by Paul Knitter a Roman Catholic Theologian- with three different approaches: (i) all religions are relative, (ii) all are essentially the same and (iii) all have a common psychological origin. Christ, to him in the final cause of salvation and he is the ultimate savior. John Cobb assigns special meaning to the term "Christ". He intends to retain the universal significance of Christ. Cobb regards Christ as source of salvation for the followers of other religions. To Edward Schillebeeckx, another modern theologian, salvation is encountered in the daily living and worshiping of humans. The documents of the second Vatican Council show that the Church does not reject anything which is true and holy in other religions. It discourages any discrimination on the basis of race or religion.

\section{References}

Anderson. M (ed.). (2014, April 12). Hans Kung. Retrieved September 18, 2014, from http://www.britannica.com Borgman, Erik (2003). Edward Schillebeeckx: A Catholic Theology of Culture (1914-1965), (London: Continuum).

Council, V. (1965, April 16). Decree Ad Gentes On The Mission Activity Of The Church. Retrieved October 10, 2014, from http://www.vatican.va/archive/hist_councils/ii_vatican_council/index.htm

Cross. F. (1997). The Oxford Dictionary of the Christian Church (3rd ed., Vol. 1), (USA: Oxford University Press), p. 1362.

Charles M. C. "John Hick's Religious World," Evangel, vol. 15, No. 1 (Spring 1997), p. 25.

Dych. W (1992). Karl Rahner, (London \& New York: Continuum), pp. 5-6.

Drummond. R (1985). Toward a New Age in Christian Theology, (Mary knoll, New York: Orbis Books), pp. 98-100. , 150-155.

Eliade. M "Religious Pluralism." (1987). The Encyclopedia of Religion (4th ed., Vol. 12, ed.). (New York: Macmillan), p. 331.

F .S. C, Edmund Chia (2001). Dialogue Resource Manual for Catholics in Asia (ed.). Federation of Asian Bishop' Conferences, Office of Ecumenical and Interreligious Affairs (FABC): Bangkok, Thailand, pp.1-5.

F. Knitter (1985). No Other Name?: A Critical Survey of Christian Attitudes Toward the World Religions, ( Mary knoll: New York Orbis Books), p. 143.

F. Knitter (1996). Jesus and the Other Names: Christian Mission and Global Responsibility, (Mary knoll, New York: Orbis Books), p. 6.

F. Knitter (2002). Introducing Theologies of Religions, (New York: Orbis Books), pp. 12-15.

G. D'Costa (1987). John Hick's Theology of Religions: A Critical evaluation, (New York: University Press of America), p. 2.

G. D'Costa (1997). The Modern Theologians: An Introduction to Christian Theologians in the Twentieth Century (2nd ed., ed.). (Cambridge, MA: Blackwell Publishers), pp. 268-72.

Huns. K (1976). On Being a Christian, (trans. Edward Quinn), (Garden City, New York: Doubleday), pp. 91-92.

Hick. J (1985). God Has Many Names. (Philadelphia: The Westminster Press) pp. 66-74., 30-34.

Hick. J and Paul F. Knitter (1987). The Myth of Christian Uniqueness: Toward a Pluralistic Theology of Religions (eds.). (London: SCM Press, and Mary knoll, New York: Orbis Books), pp. 15-17.

Hick. J (1977). The Myth of God Incarnate, (ed). (Philadelphia: Westminster Press), p. 181.

Hick. J (2002). John Hick: An Autobiography, (England: One World Oxford), pp. 11-24.

Hick J (1973). God and the Universe of Faith, (London: Macmillanm), pp. 99-101.

Komonchak. J and Dermot A. (1987). The New Dictionary of Theology (2nd ed., Vol. 1), (Hong Kong: Gill and Macmillan), p. 27.

Michael. G and Monika K. Hellwig, "Catholism." (2004). The Modern Catholic Encyclopedia (2nd ed. Vol. 1, eds). (USA, Minnesota: Liturgical), pp. 714-115. 
Padraic. C \& Fraiche Ryan (2010). Karl Rahner: Theologian for the Twenty-First Century (ed.). (New York: Peter Lang), pp. 4-7. Race. A (1983). Christians and Religious Pluralism, (Maryknoll, New York: Orbis Books), pp. 10-37.

Rahner, Karl (1966). Theological Investigations, (London: Darton, Longman \& Todd), Vol. 5, pp. 118-120., 121-130., 131-132., $133-134$. Schillebeeckx, Edward (1967). Vatican II: The Real Achievement, (London: Sheed \& Ward) pp. 6-59.

Schillebeeckx, Edward (1968). "Towards a Catholic Use Hermeneutics", in God Future of Man, (New York: Sheed \& Ward), p. 5. Theological Seminary, U. (2010, August 18). Paul Knitter. Retrieved December 16, 2014, from http://www.utsnyc.edu/paul-knitter The Church: Reading in Theology, (1998). (Compiled at The Gustave Weiger), (New York: P. J. Kenedy \& Sons), pp. 113-117. Without Name

Vorgrimler H (1986). Understanding Karl Rahner: An Introduction to his Life and Thoughts, (London: SCM Press Ltd), pp. 94-102. 